\title{
Broiler Response to the Utilization of Fermented Palm Oil Sludge with Phanerochaete chrysosporium and Neurospora crassa
}

\author{
Mirnawati $^{1 *}$, Gita Ciptaan ${ }^{1}$, Ade Djulardi ${ }^{1}$ and Malik Makmur ${ }^{2}$ \\ ${ }^{1}$ Department of Animal Feed and Nutrition, Faculty of Animal Science, Andalas University, Padang, 25163, West Sumatra, \\ Indonesia; ${ }^{2}$ Doctoral student, Department of Animal Feed and Nutrition, Faculty of Animal Science, Andalas University, \\ Padang, 25163, West Sumatra, Indonesia \\ *Corresponding author: mirnawati@ansci.unand.ac.id
}

Article History: 21-363 Received: 01-Aug-21 Revised: 16-Aug-21 Accepted: 18-Aug-21
A BS T RA C T
Palm Oil Sludge (POS) had the potential as an ingredient of broiler ration. POS must be processed by fermentation of P.
chrysosporium and N. crassa to increase nutritional value. This research aimed to evaluate the utilization of Fermented
Palm Oil Sludge (FPOS) utilization with P. chrysosporium and N. crassa in broiler rations. This experiment used one
hundred and sixty mixed-sex a-day-old chicks (DOC) Cobb CP 707 breed of broiler procured from Charoen Pokphand
Indonesia. The broilers were placed in 20 wire cages; each unit consisted of 8 birds. Feeding treatment was carried out for
35 days. The ration was composed of 22\% iso-protein and $3000 \mathrm{kcal} / \mathrm{kg}$ of iso-metabolic energy. The design of this
experiment is a completely randomized design with five treatments and four replications. Treatments were: T1) 0\% FPOS
(control diet), T2) 15\% FPOS, T3) 20\% FPOS, T4) 25\% FPOS and T5) 30\% FPOS in broiler ration. Feed intake, body
weight gain, feed conversion ratio, body weight, carcass percentage, and abdominal fat percentage) were found to be
significantly (P<0.05) decreased with any treatment except carcass weight (P>0.05) as compared to the control group. In
conclusion, FPOS with the combination of P. chrysosporium and N. crassa could be used up to $25 \%$ in rations of broiler.

Key words: Broiler, Fermented palm oil sludge, Neurospora crassa, Phanerochaeta chrysosporium.

@202I IJVS - All Rights Reserved

\section{INTRODUCTION}

Palm Oil Sludge (POS) is waste product of crude palm oil production and makes up $2 \%$ of the yield from the fruit bunches but is often unused and considered a source of pollution. That is because it has a low nutritional value, being high in crude fiber and low in protein or amino acid content (Sinurat 2000). POS contains $13 \%$ crude protein, $12.3 \%$ crude fat, $32.1 \%$ crude fiber and $1105.9 \mathrm{kcal} / \mathrm{kg}$ metabolic energy (Mirnawati et al. 2017). Based on Noferdiman, 2004 research that palm oil sludge contains $7.3 \%$ hemicellulose and $14.2 \%$ lignin. Unlike its relatively high nutritional content, its utilization is still limited to $5 \%$ in poultry ration (Sinurat et al. 2000). That is due to the indigestibility of the crude fibers, especially cellulose and lignin.

In order to enhance the usage of POS in the broiler's diet, fermentation was conducted. Fermentation was used to increase digestibility by breaking down the fiber, while also enhancing flavor and aroma, finally resulted in the higher nutritional content of ingredients (Mirnawati et al. 2019a; Mirnawati et al. 2019b; Mirnawati et al. 2019c). High CF and lignin in POS required molds to produce enzymes to hydrolyze lignin i.e., $P$. chrysosporium mold. $P$. chrysosporium is white-rot mold which known for its capability to reduce lignin (Zeng et al. 2010), and produce high ligninase and cellulase (Howard et al. 2003). Noferdiman and Yani (2013) has shown that FPOS with 6\% $P$. chrysosporium inoculums for eight days had $12.2 \%$ less crude fiber and $8,9 \%$ lignin. It also had $14.1 \%$ more crude protein and can replace standard chicken feed up to $15 \%$.

Mirnawati et al. (2010) found that FPOS could increase the content of crude protein to $20.4 \%$, crude fiber decreased to $23 \%$ and decreased crude fat to $3.7 \%$ and increase the digestibility of the crude fiber up to $48.4 \%$, nitrogen retention $56.2 \%$ and metabolic energy 2024.3 $\mathrm{kcal} / \mathrm{kg}$. Based on results of Mirnawati et al. (2018), FPOS with $N$. crassa could not replace more than $22 \%$ of standard broiler ration. Mirnawati et al. (2019a) studied on FPOS of $P$. chrysosporium and $N$. crassa fungi, using a ratio of 4 :

Cite This Article as: Mirnawati, Ciptaan G, Djulardi A and Makmur M, 2022. Broiler response to the utilization of fermented palm oil sludge with Phanerochaeta chrysosporium and Neurospora crassa. International Journal of Veterinary Science 11(2): 215-220. https://doi.org/10.47278/journal.ijvs/2021.089 
1 for 13 days. This gave dry matter $89.3 \%$, crude protein $26.2 \%$, crude fiber $14.5 \%$, crude fat $2.2 \%$, calcium $0.3 \%$, phosphor $0.7 \%$, lignin $14.5 \%$, nitrogen retention $58.2 \%$, a digestibility of crude fiber $57.7 \%$ and metabolic energy $2787.9 \mathrm{kcal} / \mathrm{kg}$.

From the above data it may be seen that there is an increase in the content and quality of FPOS with $P$. chrysosporium and $N$. crassa. This result suggested that both $P$. chrysosporium and $N$. crassa used to fermented POS, would be a high-quality ingredient for poultry. This study aimed to specify the effect of feed ingredient on animal performance and determine the percentage in the ration. Field testing is required to search the optimal percentage of FPOS that could be utilized in broiler feed and its impact on performance.

\section{MATERIALS AND METHODS}

\section{Animal Ethics}

Animal experiments were carried out based on the Republic of Indonesia Law No. 18 of 2009 (section 66) chapter animal ethics that related to holding, rearing, and slaughtering and proper treatment and care for animals.

\section{Broiler Maintenance}

One hundred and sixty mixed-sex a-day-old breed cobb CP 707 broiler chicks from Charoen Pokphand Indonesia were raised in twenty $80 \times 60 \times 50 \mathrm{~cm}$ wire cages. Each cage held eight broiler and had its feeding and drinking stations and 60-watt incandescent lamps for heating and lighting. Rations were prepared by mixing commercial feed CP 511 with yellow corn, fish meal, soybean meal, rice bran, vegetable oil, top mix, and FPOS. Maintenance period was carried out up to five weeks (35 days).

\section{Feeding Formulation}

FPOS was made of $80 \%$ POS and $20 \%$ rice bran, which then fermented (at a room temperature) with $P$. chrysosporium and $N$. crassa with a ratio of $4: 1$ of each inoculum respectively. The product was incubated for 13 days in an incubator, got harvested, and then dried in an oven at temperature of $60^{\circ} \mathrm{C}$. After that, FPOS finally grounded and ready as feedstuff for poultry. The ration contained $22 \%$ iso-protein and $3000 \mathrm{kcal} / \mathrm{kg}$ of isometabolic energy. Details of composition were seen from Table 1.

\section{Experimental Design}

The research method used was an experimental method of Completely Randomized Design (CRD) with five treatments and four replications. Treatments were $\mathrm{T} 1$, T2, T3, T4, T5 with the use of $0,15,20,25$ and $30 \%$ fermented palm oil sludge (FPOS) respectively. The variables observed were feed intake (FI), body weight gain (BWG), feed conversion rate (FCR), body weight (BW), carcass weight $(\mathrm{CW})$, carcass percentage $(\mathrm{CP})$ and percentage of abdominal fat (AFP) for each broiler were measured following Maslami et al. (2019).

\section{Statistical Analysis}

The data collected were processed with ANOVA (Analysis of Variance) and DMRT (Duncan's Multiple Range Test) was performed as post hoc test (Steel and Torie 1995).

\section{RESULTS}

\section{Feed Intake (FI)}

Significant $(\mathrm{P}<0.05)$ effect was seen on analysis of statistic on FI after giving FPOS up to $30 \%$ in the ration. DMRT showed significant effect on Treatment T5 but nonsignificantly $(\mathrm{P}>0.05)$ different on other treatments (Fig. 1). Giving FPOS up to $25 \%$ in the ration can match the consumption of the control ration. However, feed consumption decreased in T5 treatment (30\% FPOS).

\section{Body Weight Gain (BWG)}

Significant $(\mathrm{P}<0.05)$ effect also seen on statistical analysis of BWG after giving FPOS up to $30 \%$ in the ration. DMRT showed non-significantly different on treatment T1, T2, T3 and T4, but significant effect on Treatment T5 (Fig. 1). Giving FPOS up to $25 \%$ in the ration can match the body weight gain of the control ration. However, body weight gain decreased in T5 treatment (30\% FPOS)

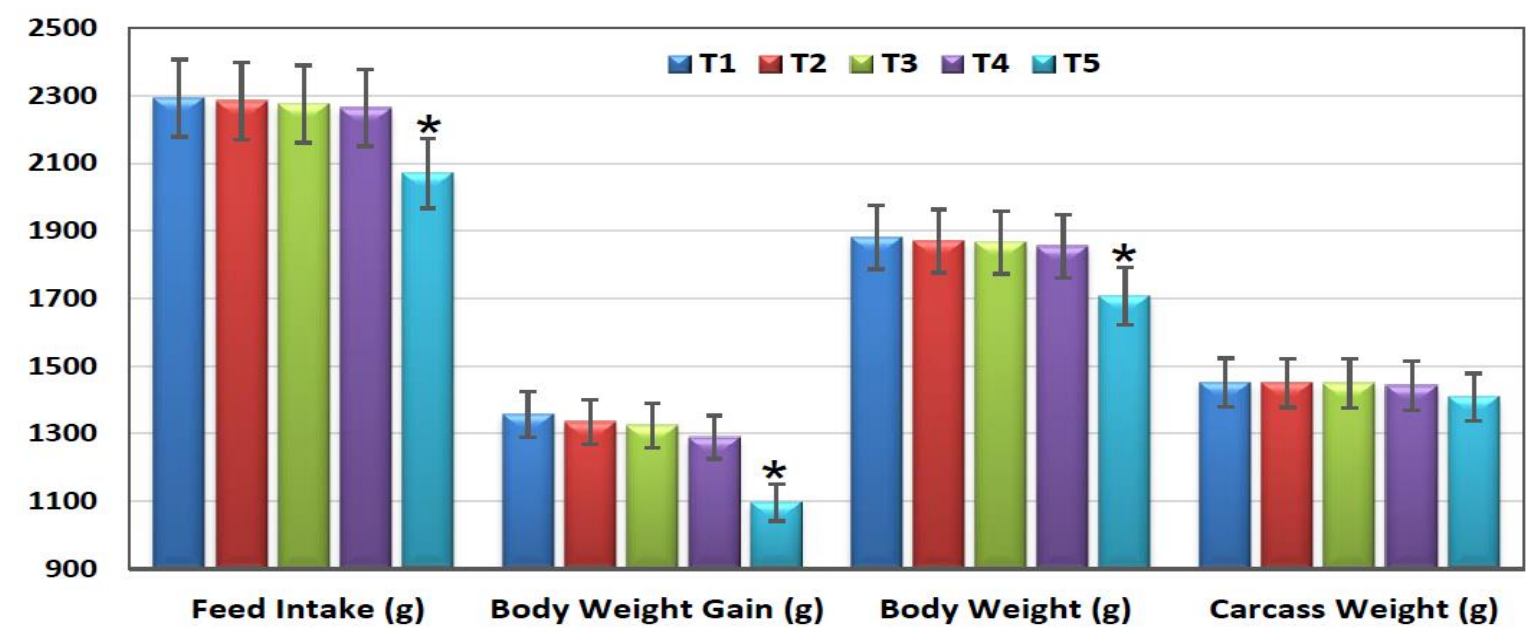

Fig. 1: Effect of dietary fermented palm oil sludge (FPOS) on broiler feed intake, body weight gain, body weight and carcass weight for 35 days. Inclusion of FPOS in T1 to T5 was 0\% (T1-Control), 15\% (T2), 20\% (T3), 25\% (T4), and 30\% (T5), respectively. Bar bearing asterisk in a specific parameter differ significantly $(\mathrm{P}<0.05)$ than that of control group. 
Table 1: Feeding composition (\%) of treatment/rations

\begin{tabular}{llllll}
\hline Feed ingredients & \multicolumn{5}{c}{ Treatment Ration } \\
\cline { 2 - 6 } & $\mathrm{T} 1$ & $\mathrm{~T} 2$ & $\mathrm{~T} 3$ & $\mathrm{~T} 4$ & $\mathrm{~T} 5$ \\
\hline CP 511 commercial feed & 10 & 10 & 10 & 10 & 10 \\
Yellow corn & 53 & 45 & 42 & 40 & 39.5 \\
Rice bran & 6 & 4 & 4 & 3 & 1 \\
Soybean meal & 13 & 8 & 6 & 4 & 1.5 \\
FPOS & 0 & 15 & 20 & 25 & 30 \\
Fish meal & 16 & 16 & 16 & 16 & 16 \\
Coconut oil & 1.5 & 1.5 & 1.5 & 1.5 & 1.5 \\
Top mix & 0.5 & 0.5 & 0.5 & 0.5 & 0.5 \\
Total & 100 & 100 & 100 & 100 & 100 \\
\hline
\end{tabular}

Table 2: Nutrient composition (\%) and energy contents composition and metabolic energy $(\mathrm{kcal} / \mathrm{kg})$ in treatment feed

\begin{tabular}{llllll}
\hline Item & \multicolumn{5}{c}{ Treatment Ration } \\
\cline { 2 - 6 } & T1 & T2 & T3 & T4 & T5 \\
\hline Crude protein & 22.05 & 22.44 & 22.45 & 22.46 & 22.28 \\
Crude fat & 4.05 & 4.01 & 4.00 & 3.98 & 3.94 \\
Crude fibers & 4.03 & 5.46 & 5.97 & 6.42 & 6.79 \\
Calcium & 1.27 & 1.24 & 1.23 & 1.21 & 1.19 \\
Phosphor & 0.66 & 0.71 & 0.73 & 0.75 & 0.77 \\
Energy metabolism & 3028 & 3032 & 3025 & 3036 & 3039
\end{tabular}

\section{Body Weight (BW)}

Significant $(\mathrm{P}<0.05)$ effect was seen from analytical statistic of FBW after giving FPOS up to $30 \%$ in the ration. DMRT showed significant effect on Treatment T5 but nonsignificantly different on treatment $\mathrm{T} 1, \mathrm{~T} 2, \mathrm{~T} 3$ and T4 (Fig. 1). Giving FPOS up to $25 \%$ in the ration can match body weight of the control ration. However, body weight decreased in $\mathrm{T} 5$ treatment (30\% FPOS).

\section{Feed Conversion Ratio (FCR)}

Statistical analysis of FCR showed significant effect $(\mathrm{P}<0.05)$ after giving FPOS up to $30 \%$ in the ration. DMRT showed non-significantly different on treatment $\mathrm{T} 1, \mathrm{~T} 2, \mathrm{~T} 3$ and T4, but significant effect on Treatment T5 (Fig. 2). Giving FPOS up to $25 \%$ in the ration can match the feed conversion of the control ration. However, body weight gain decreased in T5 treatment (30\% FPOS).

\section{Carcass Percentage (CP)}

After administration of $30 \%$ FPOS in ration, analytical statistic on $\mathrm{CP}$ showed a significant effect $(\mathrm{P}<0.05)$. DMRT showed non-significantly different on treatment $\mathrm{T} 1, \mathrm{~T} 2, \mathrm{~T} 3$ and T4, but significant effect on T5 (Fig. 3). Giving FPOS up to $25 \%$ in the ration can match the carcass weight of the control ration. However, carcass weight decreased in T5 treatment (30\% FPOS).

\section{Abdominal Fat Percentage (AFP)}

Statistical analysis on AFP (Fig. 4) showed a significant $(\mathrm{P}<0.05)$ effect after giving FPOS up to $30 \%$ compared to control treatment. However, giving FPOS up to $30 \%$ in the ration can't reach the AFP from control ration. Broiler abdominal fat percentage decreased in $\mathrm{T} 2$ treatment (15\% FPOS).

\section{DISCUSSION}

As fermentation occurred, FPOS product had good content and quality, because of the enzyme activity produced by microbes that can break down the complex into simple

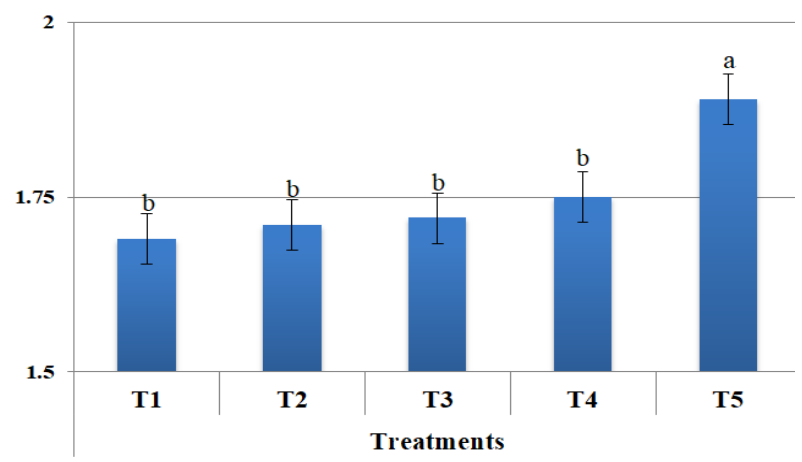

Fig. 2: Effect of dietary fermented palm oil sludge (FPOS) on broiler feed conversion ratio for 35 days. Inclusion of FPOS in T1 to T5 was $0,15,20,25$, and $30 \%$, respectively. Bar bearing different letters differ significantly $(\mathrm{P}<0.05)$.

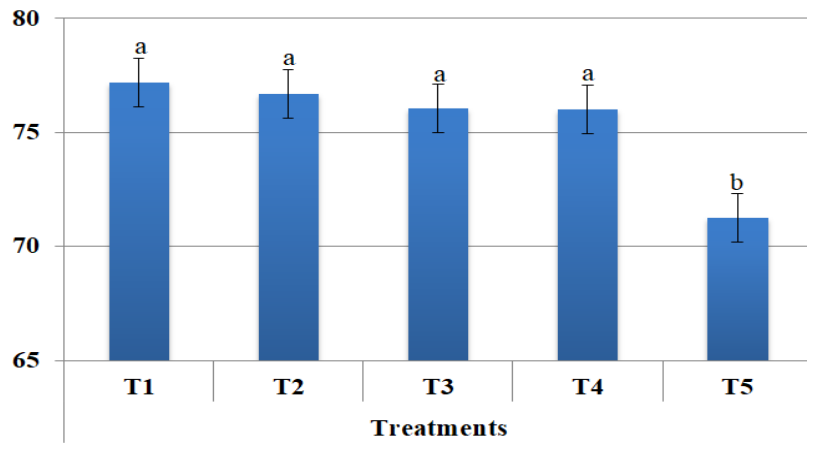

Fig. 3: Effect of dietary fermented palm oil sludge (FPOS) on broiler carcass percentage (\%) for 35 days. Inclusion of FPOS in $\mathrm{T} 1$ to $\mathrm{T} 5$ was $0,15,20,25$, and $30 \%$, respectively. Bar bearing different letters differ significantly $(\mathrm{P}<0.05)$.

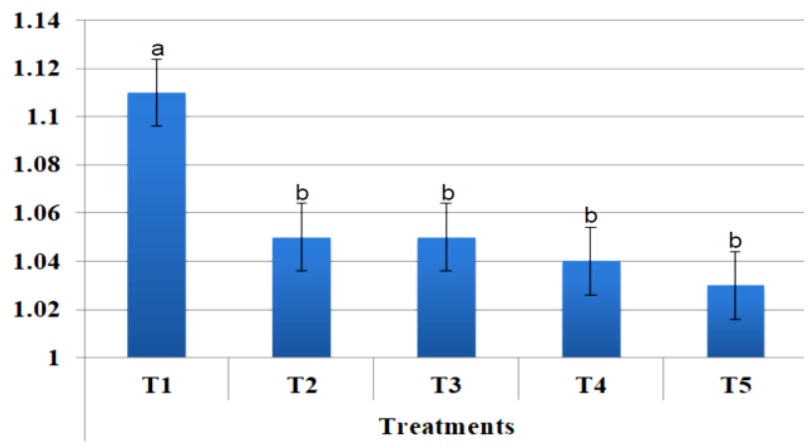

Fig. 4: Effect of dietary fermented palm oil sludge (FPOS) on broiler abdominal fat percentage $(\%)$ for 35 days. Inclusion of FPOS in T1 to T5 was 0, 15, 20, 25, and 30\%, respectively. Bar bearing different letters differ significantly $(\mathrm{P}<0.05)$.

materials so that they are easier to digest by the livestock who consume them. Besides that, fermented products can increase aroma, taste and are more palatable and easy to digest, of course, will be affected to consumption (Mirnawati et al. 2017; Sinurat et al. 2014). The decrease in feed consumption in T5 treatment (30\% FPOS) was caused by high crude fiber of $6.8 \%$ (Table 2). That is hard for chickens to digest limiting the amount they could eat. Fiber content is known to limit the amount that is consumed (Hidanah et al. 2013). The high crude fiber in the ration makes chickens felt full quickly and therefore its use in poultry feed should be limited at about $3-6 \%$ for broiler. The average feed consumption obtained during the study 
ranged from 2069.1-2292.5g/head/weeks. This result is higher than the feed consumption obtained by Ara et al. (2015) of 2043-2219.3g/head/weeks using Azolla.

Administration of FPOS up to the level of $25 \%$ of the feed had no significant effect on body weight gain as compared to the control. This result was expected because the feed consumption was not significantly different either. The nutrients and energy consumed is utilized by broiler in the formation of body tissues, so if these are constant, the broiler body weight gain produced will also be the same (Yaophakdee et al. 2018). Thomas et al. (2008). The digestibility of nutrients and the energy utilization from the ration influenced body weight gain, while feed consumption is proportional to increase in body weight (Ara et al. 2015). The smaller body weight gain of broiler fed $30 \%$ FPOS (T5) because of the high amount of crude fiber (6.79), which the broiler cannot digest. The amount of this feed that was consumed by the broiler was less. In addition, this high level of the crude fiber reduces the utilization of other nutrients such as protein and results in suboptimal growth (Maslami et al. 2019). Body weight gain is known to decrease with higher crude fiber content (Singh et al. 2017). Mean BWG of broiler obtained during the study ranged from 1289.1-1356.6 g/head/weeks. This result is higher than the BWG of broiler by Supriyati et al. (2015) of $1153-1271 \mathrm{~g} /$ head/weeks using fermented rice bran (FRB) with Bacillus amyloliquefaciens and humic substances.

The results showed that giving FPOS up to $25 \%$ in the diet had non-significant effect on the feed conversion. Because the comparison between ration consumption and body weight gain also shows the same result. The quantity of ration was consumed and the amount of weight gain will determine the conversion rate of the ration. According to Ferket and Gernat (2006) the value of feed conversion is influenced by how much of rations consumed and the chicken weight gained. Supriyati et al. (2015) states that the treatment with the same ration consumption and body weight gain will lead to the non-significant conversion of rations.

The significantly lower conversion rate for FPOS of $30 \%(\mathrm{P}<0.05)$ because of the high value of crude fiber resulting in inefficient digestion resulting in reduced weight gain. The feed grade is known to have a significant effect on both consumption and weight gain (Mirnawati et al. 2011). The average FCR obtained during the study was ranged between 1.69-1.89, which was lower than the feed conversion obtained by Ferket and Gernat (2006) of 1.811.90 using probiotics supplementations in ration. The results obtained in this study are much lower than those obtained by Mirnawati et al. (2011) which ranges from 1.88-1.91.

Administration of $25 \%$ FPOS showed non-significant difference on broiler body weight indicating the nutritional benefits of $P$. chrysosporium and $N$. crassa fermentation in which these microorganisms produce enzymes that change the complex organic compounds in the fiber into materials that were easily digested. Fermentation is known to break down indigestible carbohydrates, fats, proteins, crude fiber or other organic materials increasing digestibility (Brickett et al. 2007). The lower body weight of the broiler fed T5 ration treatment (30\% FPOS) because of the high crude fiber in the ration of $6.79 \%$, which exceeds the maximum limit for broiler. The difficulty of digesting a high crude fiber content also results in other food substances being eliminated in the feces without digestion, leading to loss of nutrients reducing body weight (Patel et al. 2015).

In addition, body weight is closely related to feed consumption (517.5-573.1 g/head/week) and broiler body weight gain (274.2-336.9g/head/week). The amount of BWG and FBW of broiler was determined by how much feed consumed by broiler. The body weight of broiler obtained during this study was best at $1854.5 \mathrm{~g} / \mathrm{head}$. This result is lower than the bodyweight of $1797.2 \mathrm{~g} / \mathrm{head}$ obtained by Mirnawati et al. (2018) who used fermented POS with $N$. crassa in diets.

Non-significant difference was found in carcass weights between treatments $\mathrm{T} 1, \mathrm{~T} 2, \mathrm{~T} 3$ and $\mathrm{T} 4$. Carcass weight is also influenced by body weight, thus large body weight will result in large carcass weight. Zhang et al. (2020) carcass weight was presented as the percentage/relative to live body weight of broiler. Hence, any increase in the absolute carcass weight would not result in significant statistical values as the increased carcass weight was parallel with the increase in final body weight of broiler. The significantly lower conversion rate for FPOS of $30 \%$ because it contained the highest amount of fiber-rich FPOS resulted in significantly lower carcass weights, as well as lower body weights as this crude fiber content, exceeds the tolerance limit of crude fiber that can be consumed by broiler. Besides, the carcass weight is affected by palatability. The average weight of broiler carcasses obtained during this study was around 1408.2$1451.2 \mathrm{~g} / \mathrm{head}$. A higher than mean carcass weight by Akmal and Mairizal, 2013 was found in this study, in which they obtained weights of around 1161.8-1423.7g/head.

There was non-significant difference in carcass percentage between the treatments T1, T2, T3 and T4 as up to $25 \%$ FPOS the Phanerochaete chrysosporium and Neurospora crassa fermentation provided adequate nutritional quality to produce a good amount of muscle. Carcass percentage is also affected by the accumulation of unusable abdominal fat, and the quality of the broiler carcass can be determined by the amount of abdominal fat (Shafey et al. 2014). If the feed contains high metabolic energy but lower amounts of digestible protein, this may result in more abdominal fat to be discarded and a lower quality carcass (Situmorang et al. 2013). The average carcass percentage was obtained during the study was still in the normal range of broiler carcass percentage. The carcass percentage obtained during this study was around $76 \%$. This result is higher than the carcass percentage of $69.38 \%$ obtained by Yesuf et al. (2017) who used cassava copra.

The AFP in treatment $\mathrm{T} 1$ showed significant differences on treatment T2, T3, T4, and T5. This is due to differences in crude fiber composition in ration. $\mathrm{T} 1$ has the lowest fiber content compared to other treatments. This has implications for higher formation of abdominal fat Okrathok and Khempaka (2020) confirmed giving cassava pulp as a source of dietary fiber can reduce accumulation of abdominal fat and cholesterol in broiler meat. Hidayat et al. (2016) stated that the composition of the ration given to the chicken is one of the many factors affecting the body's fat content. Differences in the percentage of abdominal fat was due to final age of broiler (at 5-6 week of age) so that the fat formed is still tiny. Optimal broiler growth occurs 
between the ages of 1 day to age 4-6 weeks. In this growth phase, food content absorbed by the livestock body are mostly used for growth, hence no excess of energy (as fat) was stored in the body. According to Salam et al. (2013) in broiler chickens, fat tissue begins to form fast at 6-7 weeks, then at that time, fat accumulation continues to take place more quickly due to abdominal fat so that chicken body weight increases (Diarra et al. 2015; Pratikno 2011). Mean AFP obtained was $1.03 \%$ to $1.11 \%$. This result is lower than the abdominal fat percentage of 1.33-1.95 obtained by Fati et al. (2019) who used Coleus amboinicus leaf's extract.

\section{Conclusion}

From the results of the present study it may be concluded that FPOS with $P$. chrysosporium and N. crassa (4:1) may be used $25 \%$ in broiler rations, as seen from the FC of $2264 \mathrm{~g} /$ head, BWG $1289.1 \mathrm{~g} /$ head, FCR $1.75 \%$, FBW $1854.5 \mathrm{~g} / \mathrm{head}, \mathrm{CW} 1408.2 \mathrm{~g} / \mathrm{head}, \mathrm{CP} 76 \%$ and AFP $1.04 \%$, which was able to compare the performance of broiler under control ration.

\section{Acknowledgment}

The authors are very thankful for the financial support from the Directorate General of Higher Education Ministry of Research Technology and Higher Education, the Republic of Indonesia in Number: 051/SP2H/LRPM/2019.

\section{Author's Contribution}

Mirnawati supervised the experiment and writing original manuscript. G. Ciptaan and A. Djulardi conducted the experiment and data analysis. M. Makmur prepared figures and finalize draft. All authors read and confirmed the final version of manuscript.

\section{REFERENCES}

Akmal and Mairizal, 2013. Performa broiler yang diberi ransum mengandung daun sengon (Albizzia falcataria) yang direndam dengan larutan kapur tohor $(\mathrm{CaO})$. Jurnal Peternakan Indonesia 15: 1. https://doi.org/10.25077/jpi. 15.1.1-6.2013

Ara S, Adil S, Banday MT and Khan MA, 2015. Feeding potential of aqua fern-azolla in broiler chicken ration. Journal of Poultry Science and Technology 3: 15-19.

Brickett KE, Dahiya JP, Classen HL and Gomis S, 2007. Influence of dietary nutrient density, feed form, and lighting on growth and meat yield of broiler chickens. Poultry Science 86: 2172-2181. https://doi.org/10.1093/ps/86.10. 2172

Diarra SS, Sandakabatu D, Perera D, Tambuaciri P and Mohammed U, 2015. Growth performance and carcass yield of broiler chickens fed commercial finisher and cassava copra meal-bassed diets. Journal of Applied Animal Research 43: 352-356. https://doi.org/10.1080/09712119. 2014.978774

Fati N, Siregar R and Sujatmiko, 2019. Addition of Coleus amboinicus, L leaf's extract in ration to percentage of carcass, abdominal fat, liver and heart broiler. Eksakta 20: 1 . https://doi.org/10.24036/eksakta/vol20-iss1/157

Ferket PR and Gernat AG, 2006. Factors that affect feed intake of meat birds: a review. International Journal of Poultry Science 5: 905-911. https://dx.doi.org/10.3923/ijps.2006.905.911

Hidanah S, Tamrin EM, Nazar DS and Safitri E, 2013. Limbah tempe dan limbah tempe fermentasi sebagai substitusi jagung terhadap daya cerna serat kasar dan bahan organik pada itik petelur. Jurnal Agroveteriner 2: 71-79.
Hidayat MN, Agustina L and Pakiding W, 2016. Abdominal fat percentage and carcass quality of broiler given probiotic Bacillus spp. Scientific Research Journal 4: 33-37.

Howard RT, Abotsi E, Jansen EL, Rensburg V and Howard S, 2003. Lignocellulose biotechnology: issue of bioconversion and enzyme production. African Journal of Biotechnology 2: 602-619. https://doi.org/10.5897/AJB2003.000-1115

Maslami V, Mirnawati, Jamsari, Nur YS and Marlida Y, 2019. Effect of glutamate supplementation as a feed additive on performance of broiler chickens. Journal of World's Poultry Research 9: 154-159. https://dx.doi.org/10.36380/jwpr. 2019.19

Mirnawati, Rizal Y, Marlida Y and Kompiang I, 2011. Evaluation of palm kernel cake fermented by Aspergillus niger as subtitutes for soybean meal protein in the diet of broiler. International Journal of Poultry Science 10: 537-541. https://dx.doi.org/10.3923/ijps.2011.537.541

Mirnawati, Djulardi A and Ciptaan G, 2017. Role of humic acid in improving the nutrient content and quality of fermented palm oil sludge. Pakistan Journal of Nutrition 16: 538-543. https://dx.doi.org/10.3923/pjn.2017.538.543

Mirnawati, Djulardi A and Ciptaan G, 2018. Effect of fermented palm oil sludge with Neurospora crassa added to rations on broiler production performance. Pakistan Journal of Nutrition 17: 487-491. https://dx.doi.org/10.3923/pjn.2018. $\underline{487.491}$

Mirnawati, Ciptaan G and Djulardi A, 2019a. The Combined effects of fungi Phanerochaete chrysosporium and Neurospora crassa and fermentation time to improve the quality and nutrient content of palm oil sludge. Pakistan Journal of Nutrition 18: 437-442. https://dx.doi.org/10.3923/ pjn.2019.437.442

Mirnawati, Ciptaan G and Ferawati, 2019b. Improving the quality and nutrient content of palm kernel cake through fermentation with Bacillus subtilis. Livestock Research for Rural Development 31: 7.

Mirnawati, Ciptaan G and Ferawati, 2019c. The effect of Bacillus subtilis inoculums doses and fermentation time on enzyme activity of fermented palm kernel cake. Journal of World's poultry Research 9: 211-216. https://dx.doi.org/10.36380/ jwpr.2019.26

Noferdiman, 2004. Uji coba limbah sawit dalam ransum ayam broiler. Majalah Ilmiah Angsana 8: 17-26.

Noferdiman and Yani A, 2013. Nutrition content of fermented palm oil sludge with Phanerochaete chrysosporium. Agripet 13: 47-52. http://dx.doi.org/10.17969/agripet.v13i2.820

Okrathok S and Khempaka S, 2020. Modified-dietary fiber from cassava pulp reduces abdominal fat and meat cholesterol contents without affecting growth performance of broiler chickens. Journal of Applied Poultry Research 1: 229-239. https://doi.org/10.1016/j.japr.2019.10.009

Patel SG, Raval AP, Bhagwat SR, Sadrasaniya DA, Patel AP and Joshi SS, 2015. Effects of probiotics supplementation on growth performance, feed conversion ratio and economics of broilers. Journal of Animal Research 5:155-160. http://dx.doi.org/10.5958/2277-940X.2015.00026.1

Pratikno H, 2011. Lemak abdominal ayam broiler Gallus sp. karena pengaruh ekstra kunyit Curcuma domestica Vahl. Bioma 13:17-24. https://doi.org/10.14710/bioma.13.1.17-24

Salam S, Fatahilah A, Sunarti D and Isroli, 2013. Bobot karkas dan lemak abdominal broiler yang diberi tepung jintan hitam (Nigella sativa) dalam ransum selama musim panas. Jurnal Sains Peternakan 11: 84-89. https://doi.org/10.20961/ sainspet.v11i2.4844

Shafey TM, Mahmoud AH, Hussein ES and Suliman G, 2014 The performance and characteristics of carcass and breast meat of broiler chickens fed diets containing flaxseed meal. Italian Journal of Animal Science 13: 3514. https://doi.org/ $\underline{10.4081 / i j a s .2014 .3514}$ 
Singh AK, Diaz Berrocoso JF, Dersjant-Li Y, Awati A and Jha R, 2017. Effect of a combination of xylanase, amylase and protease on growth performance of broilers fed low and high fiber diets. Animal Feed Science and Technology 232: 1620. https://doi.org/10.1016/j.anifeedsci.2017.07.012

Sinurat AP, Purwadaria T, Ketaren P, Zainuddin D and Kompiang IP, 2000. Utilization of palm oil sludge in poultry diet. 1 . Dried palm oil sludge and its fermented product in broiler's diet. Jurnal Ilmu Ternak dan Veteriner 5: 107-112.

Sinurat AP, Purwadaria T, Ketaren PP and Pasaribu T, 2014. Substitutions of soybean meal with enriched palm kernel meal in laying hens diet. Jurnal Ilmu Ternak dan Veteriner 19: 184-192. http://dx.doi.org/10.14334/jitv.v19i3.1081

Situmorang NA, Mahfudz LD and Atmomarsono U, 2013. Pengaruh pemberian tepung rumput laut (Glacilaria verrucosa) dalam ransum terhadap efisiensi penggunaan protein ayam broiler. Animal Agriculture Journal 2: 49-56.

Steel RGD and Torrie JH, 1995. Prinsip dan Prosedur Statistika Suatu Pendekatan Biometrik. Gramedia, Jakarta, Indonesia.

Supriyati T, Haryati, Susanti T and Susana IWR, 2015. Nutritional value of rice bran fermented by Bacillus amyloliquefaciens and humic substances and its utilization as a feed ingredient for broiler chickens. Asian-Australasian Journal of Animal Science 28: 231-238. http://dx.doi.org/ $\underline{10.5713 / a j a s .14 .0039}$
Thomas DV, Ravindran V and Ravindra G, 2008. Nutrient digestibility and energy utilisation of diets based on wheat, sorghum or maize by the newly hatched broiler chick. British Poultry Science 49: 429-435. https://doi.org/10.1080/ $\underline{00071660802213467}$

Yaophakdee N, Ruangpanit Y and Attamangkune S, 2018. Effects of palm kernel meal level on live performance and gut morphology of broiler. Agriculture and Natural Resources 52: 75-78. https://doi.org/10.1016/j.anres.2018.05.007

Yesuf KY, Mersso BT and Bekele TE, 2017. Effects of different levels of turmeric, fenugreek and black cumin on carcass characteristics of broiler chicken. Journal of Livestock Science 8: 11-17.

Zeng G, Yu M, Chen Y, Huang D, Zhang J, Huang H, Jiang R and $\mathrm{Yu} \mathrm{Z}$, 2010. Effect of inoculation with Phanerochaete chrysosporium at various time point on enzyme activities during agricultural waste composting. Bioresource Technology 101: 222-227. https://doi.org/10.1016/j. biortech.2009.08.013

Zhang X, Sun Z, Cai J, Wang G, Zhu Z, Zhao L and Cao F, 2020. Dietary supplementation with fermented Radix astragalusginkgo leaves improves antioxidant capacity and meat quality in broilers. Pakistan Journal of Zoology 52: 15711585. https://dx.doi.org/10.17582/journal.pjz/20181008081 $\underline{005}$ 